\title{
The intra-nucleus integration of mitochondrial DNA (mtDNA)in cervical mucosa cells and its relation with c-myc expression Daozhen Chen ${ }^{* \dagger}$, Wenqun $\mathrm{Xue}^{\dagger}$ and Jinying Xiang ${ }^{\dagger}$
}

\author{
Address: Center Laboratory, Wuxi Hospital for Matemaland Child Health Care, Affiliated Medical University of Nanjing, Wuxi, 214002, PR China \\ Email: Daozhen Chen* - chendaozhen@163.com; Wenqun Xue - xuewenqun@hotmail.com.cn; Jinying Xiang - wxxjy89@163.com \\ * Corresponding author †Equal contributors
}

Published: 9 September 2008

Journal of Experimental \& Clinical Cancer Research 2008, 27:36 doi:10.1 186/1756-9966-27-36

This article is available from: http://www.jeccr.com/content/27/I/36

(C) 2008 Chen et al; licensee BioMed Central Ltd.

This is an Open Access article distributed under the terms of the Creative Commons Attribution License (http://creativecommons.org/licenses/by/2.0), which permits unrestricted use, distribution, and reproduction in any medium, provided the original work is properly cited.
Received: 30 April 2008

Accepted: 9 September 2008

\begin{abstract}
Objective: To explore the relationship between the integration of mitochondrial DNA(mtDNA) in the nuclei of cervical epithelium cells and the expression of c-myc.

Methods: The expression of c-myc protein was measured by immunohistochemical test in 40 cases of the uterine cervix cancer, 30 cases of cervical intraepithelial neoplasia (CIN) and 30 cases of normal cervical epithelium; the sequence of mtDNA in the nuclei was detected by in situ hybridization technique.
\end{abstract}

Results: The detection rates of mtDNA in the nuclei of cervical epithelium cells were $27.5 \%, 13.3 \%$ and $0 \%$ in cervical carcinoma, $\mathrm{CIN}$, and normal cervical epithelium respectively. The expression rate of c-myc in cervical mucoma cells was $67 \%$ in the mtDNA sequence positive group and was significantly higher than that in the negative group (36\%).

Conclusion: The integration of mtDNA into the nuclei of cervical epithelium cells may be involved in the carcinogenesis of cervical epithelium cells and the expression of c-myc might be related to the integration of mtDNA sequence into nuclei of cervical epithelium cells.

\section{Background}

In recent years, several studies have found that point mutation of some tumors was relevant to that of mtDNA, but it is unclear for causal relation, which could not rule out the possibility of mtDNA integration to the nuclear genome and inducing carcinogenesis. Actually there were objective conditions for the intranuclear transfusion and integration of mtDNA and its fragments. Physical, chemical and certain biological factors may cause mtDNA mutations, the collapse of mitochondrial membrane, and give rise to mtDNA and its fragments dissociation into the cytoplasm. When the free mtDNA and its fragments in the cytoplasm generate excessivelly and the activity of DNAase DNAase-like materials is degraded, the free
mtDNA or its fragments probably has the similar effect of tumorgenic virus, passing through nucleopore and randomly integrating into genome DNA. The roles of mtDNA intranuclear integration could be as follows: (1) The integration fragments or integration sites do not influence the normal function of genome and have little impact on the biological characteristics of the host cells; (2) activation of a "healthy gene" enhances the body's disease resistance and promotes biological evolution; (3) oncogene activation or anti-oncogene inhibition causes cell proliferation and differentiation out of control, which finally leads to cancerization; (4) apoptosis gene activation or anti-apoptosis gene inhibition induces cells apoptosis rapidly. More and more data indicated that mtDNA integration existed 
in the nuclear genome of tumor cells. Liang etc. [1] has also found the phenomenon of mtDNA fragments intranuclear integration in early glioma cells by fluorescent in situ hybridization of chromosomes. Kamimura etc. [2] detected a section of mtDNA sequence homology in the nDNA of tumor cells, which is composted of three unconsecutive sections of mtDNA: $12 \mathrm{~S}$ rRNA, cytochrome oxidase I (COX-I) and a part of ND4L/ND4 DNA. Later Shay [3] has got the similar findings in the nuclear genome research on Hela TG cervical cancer cells. mtDNA intranuclear integration may lead to the instability of chromosome DNA and oncogene activation and/or antioncogene deactivation, which lead to abnormal cell proliferation and differentiation and finally result in cancerization.

Carcinoma of the uterine cervix is the second commonest malignancy in women only next to breast cancer. Activation of oncogene and inactivation of anti-oncogene are molecular basis of cancerization of cells. Some scholars [4] suggested that mtDNA, the unique genetic materal outside of chromosome, may be randomly integrated into genome DNA and activate oncogene or inactivate antioncogene, and finally induce the development of tumor. Previous study of our lab [5] has found that higher frequency of mtDNA mutation existed in cervical cancer. The purpose of this study was to enrich the study of molecular mechanism of cervical cancer by detecting intra-nucleus integration of mtDNA segment in cervical mucosa cells and exploring its correlation with c-myc (an important oncogene).

\section{Materials and methods Cases}

40 patients with cervical cancer were collected from 2000 to 2004 for biopsy samples, including 34 cases of squamous cell carcinoma and 6 cases of adenocarcinoma. According to FIGO clinical staging standard, 13 cases were in stage I and 27 cases were in stage II; These cases were classified as histological grading standard: 9 cases in grade I, 21 cases in grade II and 11 cases in grade III. radical hysterectomy plus pelvic curettage of lymph node was performed for all these patients whose age ranged from 36 to 71 years old, and median age was 59.5 years old. 30 cases of CIN and 30 cases of normal cervical epithelia were taken as control. Patients were informed of the nature, goals, potential benefits, and risks of participating in the study and signed a written consent form approved by the Institutional Ethics Committee.

\section{Pathological section and staining}

Tissues of cervical cancer were taken, fixed with $10 \%$ formaldehyde and embedded with paraffin, HE staining or IHC were used for sections. Some tissues were taken for 5 $\mu \mathrm{m}$ frozen sections, fixed with $4 \%$ paraformaldehyde for hybridization in-situ.

\section{DNA hybridization in-situ}

mtDNA probe sequence refered to the relative literature [6]. Probe marks adopted Roche random primer digoxin marks and reagent kits, according to the manufacture's instruction. $2 \mu \mathrm{g}$ of restriction endonuclease HaeIII (GG $\downarrow$ $\mathrm{CC}$ ) and HpaII (C $\downarrow \mathrm{CGG}$ ) were respectively added to $1 \mu \mathrm{g}$ of mtDNA probe in $37^{\circ} \mathrm{C}$ water bath for $2 \mathrm{~h}$ for enzymatic digestion which was prepared for hybridization.) Dilution of the probe was $1.5 \mathrm{ng} / \mu \mathrm{l}$. The hybridization solution contained: $50 \%$ deionized formamide, $0.1 \% \mathrm{~N}$ Lauroylsarcosine, $0.02 \%$ SDS, 2\% blocking reagent and 5 $\times$ SSC. Hybridization solution without probe was used as negative control. The steps of the hybridization in situ were as follows: (1) each section was initially treated with $0.01 \mathrm{~mol} / \mathrm{l} \mathrm{HCL}$ and proteinase $\mathrm{K}$ at $37^{\circ} \mathrm{C}$ for $30 \mathrm{~min}$, then washed with $0.1 \mathrm{~mol} / \mathrm{L}$ glycine for $5 \mathrm{~min}$ and fixed with 4\% paraformaldehyde for $5 \mathrm{~min}$; (2) Prehybridization: $30 \mu \mathrm{l}$ prehybridization solution was added to each section, at $37^{\circ} \mathrm{C}$ for $30 \mathrm{~min}$; (3) Hybridization: $30 \mu \mathrm{l}$ hybridization solution with probe was added to each section at $37^{\circ} \mathrm{C}$ for $16 \mathrm{~h}$; (4) $30 \mu \mathrm{l}$ digoxin antibody labeled with alkaline phosphoric enzyme was added at $42^{\circ} \mathrm{C}$ for $0.5 \mathrm{~h}$; (5) coloration: the section was colored by NBT/ BCIP for 30 60 min for microscopic examination and photograph. If the nucleus had hyacinthine staining but the intercellular substance and control hadn't such staining, it was regarded as positive expression.

\section{Detection of the c-myc expression by immunohistochemical test}

Immunohistochemical reagent c-myc monoclonal antibody produced by U.S. Symed (purchased from Beijing Zhongshan Biological Technology Company, China). Operating steps: (1) the section was dewaxed and then put into water. (2) repaired for $20 \mathrm{~min}$ by hot platform. (3) The normal horse serum was added to section for $20 \mathrm{~min}$ at 1:50 dulitions for blocking) (4) the section was incubated with monoclonal antibody at $1: 60$ dulitions at $4{ }^{\circ} \mathrm{C}$ overnight; (5) 1:120 double (secondary) antibody was added at room temperature for $60 \mathrm{~min}$ (6) SAHRP 1:150 for $60 \mathrm{~min}$ at room temperature. (7) DAB staining. (8) Hematein double staining, dehydration, transparent mount. The standard of c-myc positive reaction: the reaction product of c-myc positive reaction was brown particles, distributed in cell nucleus, it was regarded as positive expression if the percentage of possive cells was more than $30 \%$ under 10 high power fields.

\section{Statistical methods}

The statistical analysis was performed by using SAS (6.12_version)) statistical software. The statistical com- 
parisons between groups were performed by $\chi^{2}$ test, $P<$ 0.05 was considered statistically significant.

\section{Results}

\section{Intranucleus integration of mtDNA sequence}

mtDNA sequence was detected in 15 cases of cervical mucosa nucleus by hybridization in-situ (see Fig 1). Integration rates in normal cervix, CIN and cervical cancer were $0 \%, 13.3 \%$ and $27.5 \%$ respectively. Difference among the three groups was significant $\left(\chi^{2}=9.054, P<\right.$ 0.05 , see Table 1 ).

\section{C-myc oncogene expression}

Positive expression was diffused in cervical squamous cell cancer but mesenchymal was negative (see Fig 2). In CIN, positive expression was seen in atypical proliferation of epithelium whereas normal epithelia and mesenchyma were negative. The expression rates of C-myc in normal cervix, CIN and cervical cancer were 7\%, 33\% and 73\% respectively. Difference among the three groups was significant $\left(\chi^{2}=10.658, \chi^{2}=27.503, P<0.05\right.$, Table 2$)$.

\section{Relationship between intranuleus integration of mtDNA sequence and C-myc oncogene expression}

In 100 samples, 41 were c-myc positive, of which 10 cases were positive of mtDNA hybridization in-situ nucleus staining; 59 cases were c-myc negative, of which 5 cases were positive of mtDNA hybridization in-situ nucleus staining. Difference was significant $\left(\chi^{2}=4.81, P<0.05\right)$ (Table 3)

\section{Discussion}

Proper insertion of mitochondria gene into nucleus genome is important in biological evolution, but improper insertion may be one of the main causes of certain genetic diseases, malformation or tumors. Hu Yide et al [7] adopted gene transfer technology to transfect mtDNA fragment to mouse NIH3T3, which induced cells malignant transformation. It suggested that mtDNA integration in nucleus was an important factor to promote cells cancerization. Ling Xianlong et al [8] also found intranucleus integration of mtDNA fragment in cell nucleus of gastric cancer. Shay et al [9] found CoIII of mtDNA in Hela TG cells arranged in c-myc gene. The resulting mRNA contained not only genetic information

Table I: Integration of mtDNA in nuclei of cervical epithelium cells

\begin{tabular}{lccccc}
\hline Groups & $\mathrm{n}$ & + & - & $\begin{array}{c}\text { integration } \\
\text { rate (\%) }\end{array}$ & $\mathrm{P}$ value \\
\hline $\begin{array}{l}\text { Cervical } \\
\text { carcinoma }\end{array}$ & 40 & 17 & 23 & $42.50 \%$ & $\chi^{2}=9.054(\mathrm{P}<0.05)$ \\
CIN & 30 & 4 & 26 & $13.30 \%$ & $\chi^{2}=9.054(\mathrm{P}<0.05)$ \\
Normal cervix & 30 & 0 & 30 & $0 \%$ & \\
& & & & &
\end{tabular}
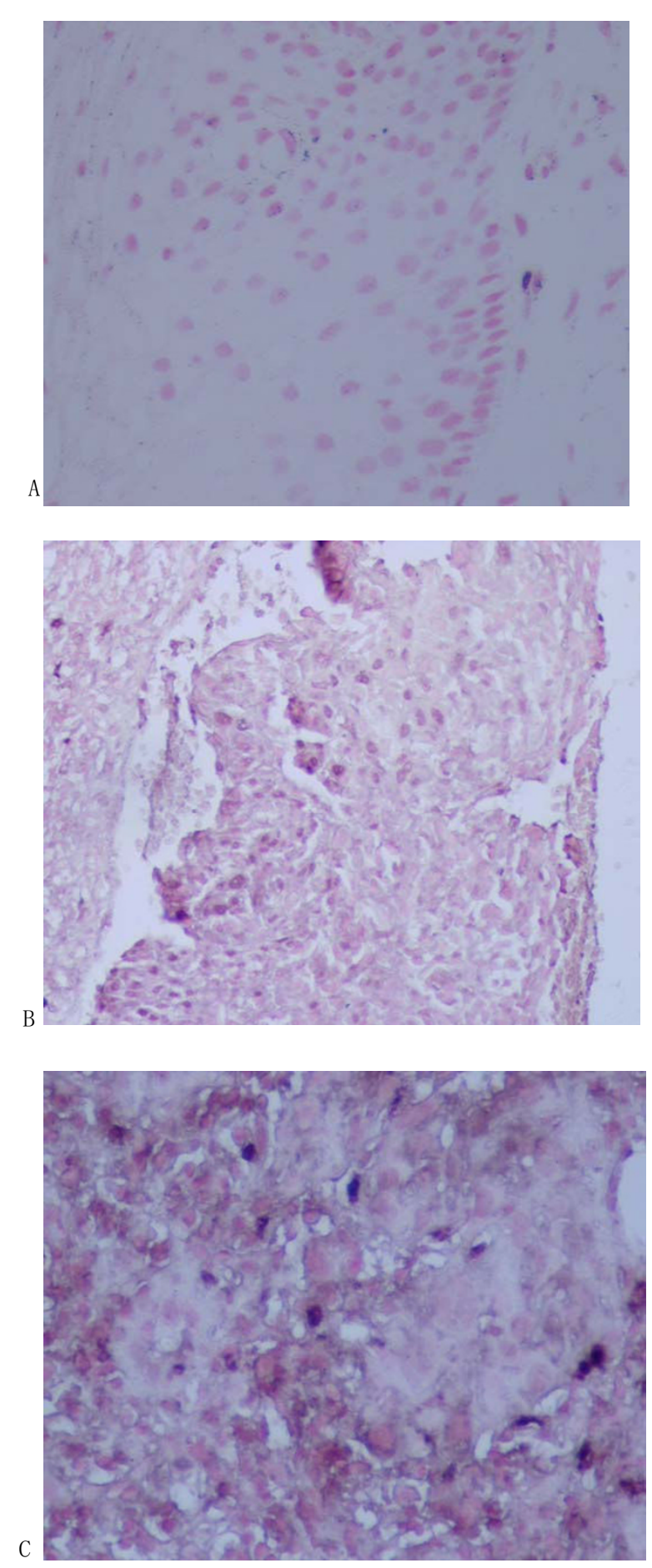

\section{Figure I}

Integration of mtDNA in the nuclei of cervical epithelium cells detected by in situ hybridization The nucleus had hyacinthine staining but the intercellular substance and control hadn't such staining, it was regarded as positive expression. (A: normal cervix tissure; B: CIN tissure; C: cervical cancer tissure) 
Table 2: The expression of c-myc in cervical epithelium cells

\begin{tabular}{lccccc}
\hline Groups & $\mathrm{n}$ & positive & negative & $\begin{array}{c}\text { positive } \\
\text { rate }(\%)\end{array}$ & $\mathrm{P}$ value \\
& & & & & \\
\hline $\begin{array}{l}\text { Cervical } \\
\text { carcinoma }\end{array}$ & 40 & 29 & $\mathrm{II}$ & $73 \%$ & $\chi^{2}=10.658(\mathrm{P}<0.05)$ \\
CIN & 30 & 10 & 20 & $33 \%$ & $\chi^{2}=27.503(\mathrm{P}<0.05)$ \\
$\begin{array}{l}\text { Normal } \\
\text { cervix }\end{array}$ & 30 & 2 & 28 & $7 \%$ & $\chi^{2}=27.503(\mathrm{P}<0.05)$ \\
& & & & &
\end{tabular}

from c-myc, but also from CoIII. Our lab had similar findings in FISH of Hela cells of cervical cancer cultured in vitro.

C-myc oncogene was located in chromosome 8q24, total length $6 \sim 7 \mathrm{~kb}$. It had 3 exon, coding protein consists of 49 amino acid residues, molecular weight reaches 64/67 $\mathrm{kDa}$. C-myc over-expression and proliferation was often found in cervical cancer tissue. Ngan [10] adopted immunohistochemical technology to study 45 cases of normal cervical tissue, 38 cases of stage I CIN, 37 cases of stage II CIN and 43 cases of stage III CIN: The results showed that c-myc expression was active in poorly developed cells. It suggested that in CIN evolution, c-myc was an important proto-oncogene. Aoyama [11] tested various pathological cervical tissues with PCR. He found that c-myc oncogene was easily proliferated and (or) over-expressed. Present study first used IHC technology to explore c-myc expression in cervical tissues. Data showed that c-myc expression decreases gradually in cervical cancer, CIN and normal cervical tissue. With the increase of malignancy, positive expression became stronger, low differentiation squamous cell cancer was stronger than high differentiation one and grade III CIN was stronger than grade I CIN, which basically conformed to the reports in literature [1].

In order to exploring the correlation between c-myc oncogene expression and mtDNA integration into genome, DNA hybridization in-situ on frozen sections was also used in present study. The results showed that in the course of chronic cervical inflammation $\rightarrow$ CIN $\rightarrow$ cervical cancer, detection rate of mtDNA sequence arranged in DNA genome increased in turn, which suggested its relation with the development of cervical cancer. C-myc gene expression rates of cervical mucosa cells were $67 \%$ in mtDNA detection group and $36 \%$ in non-detection group respectively. Thus, We infered that acted by certain physical, chemical and biological factors, mtDNA mutation took place. Mutation in D-LOOP may change affinity of trans factors related to mitochondria DNA and replication, copy number of mtDNA therefore increases obviously, normal metabolic balance was damaged, free mtDNA and its fragments were excessive and activity of nucleic acid catabolic enzymes in cells decreases mean-
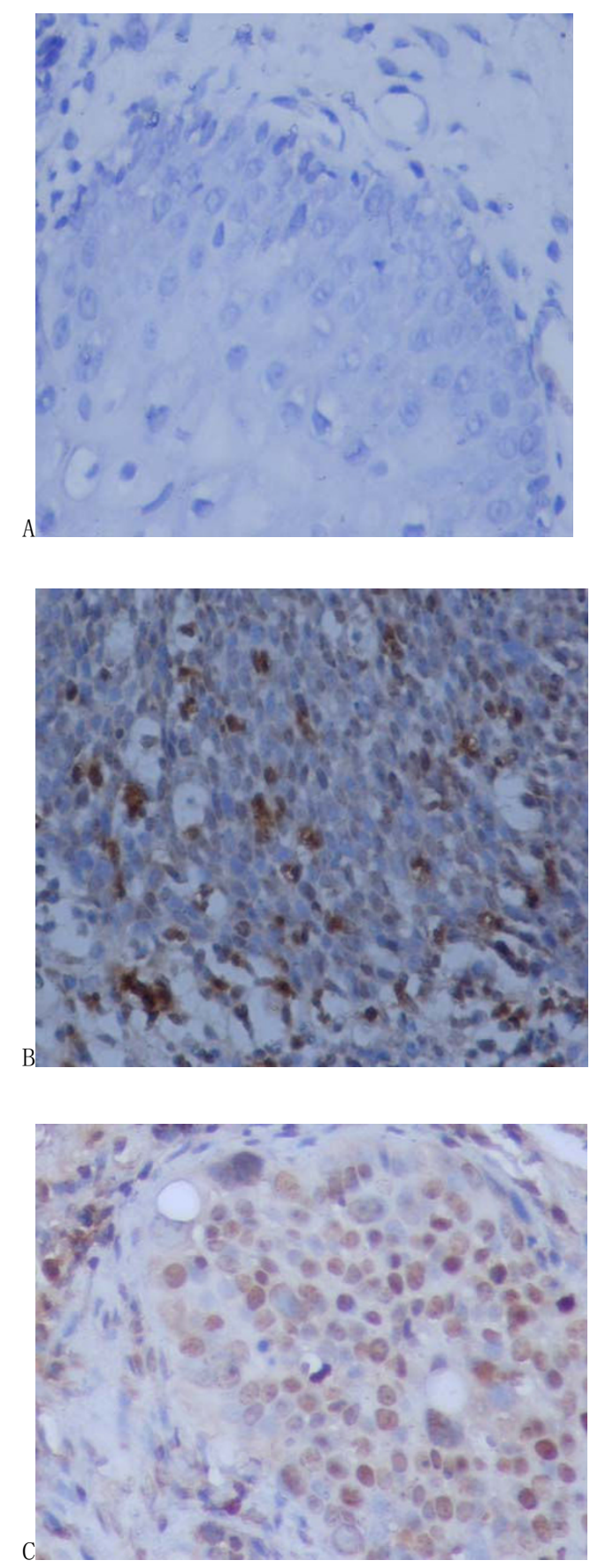

\section{Figure 2}

The expression of c-myc in cervical epithelium cells detected by immunohistochemical test. The standard of c-myc positive reaction: the reaction product of c-myc positive reaction was brown particles, distributed in cell nucleus, it was regarded as positive expression if the percentage of possive cells was more than $30 \%$ under 10 high power fields. (A: normal cervix tissure; $\mathrm{B}$ : $\mathrm{CIN}$ tissure; C: cervical cancer tissure). 
Table 3: Relationship between integration of mtDNA in nucleus and the expression of c-myc gene

Sequence intranuleus integration $(n)$

c-myc oncogene expression ( $n$ )

$P$ value

\begin{tabular}{lccc}
\hline & negative & positive & \\
negative & 54 & 5 & $\chi^{2}=4.81(\mathrm{P}<0.05)$ \\
positive & 31 & 10 & $\chi^{2}=4.81(\mathrm{P}<0.05)$ \\
\hline
\end{tabular}

time, mtDNA and its fragments were free outside mitochondria, it had similar effect of cancerous virus, arranged randomly into nucleus genome and activated oncogene or inhibited anti-oncogene, which influenced cell proliferation and differentiation and developed tumor.

Research already found that nucleus DNA and mtDNA might wander in cells [12]. Mitochondria RNA can be reversely transcripted into mtDNA in cytoplasm, there is nucleopore on membrane and DNA ligase in nucleus. So integration of mtDNA in nucleus gene may induce canceration of cells, change of mitochondria structure and quantity increase. Advanced study was needed to confirm the hypothesis above.

Present study detected intranucleus integration of mtDNA fragment in cervical mucosa cells, and analyzed the correlation between mtDNA fragment integration and c-myc expression. In conclusion, We tentatively assumed that Integration of mtDNA into nuclei of cervical epithelium cells may be involved in the carcinogenesis of cervical epithelium cells and expression of c-myc gene might be related to integration) of mtDNA sequence into nuclei of cervical epithelium cells. It provided new clues to reveal molecular mechanism of cervical cancer.

\section{Competing interests}

The authors declare that they have no competing interests.

\section{Authors' contributions}

DC conceived of the study, and participated in its design and coordination. WX carried out immunohistochemical test, drafted the manuscript and collected all of cervical cancer samples. JX carried out the DNA hybridization insitu, participated in the design of the study and performed the statistical analysis. All authors read and approved the final manuscript.

\section{Acknowledgements}

This work was supported by a grant BK2007023 from Jiangsu province Natural Science Foundation of China.

\section{References}

I. Liang BC: Evidence for association of mitochondrial DNA sequence amplifocation and muclear localization in human low-grade gliomas. Mutat Res 1996, 354(I):27-33.
2. Kamimura N, Ishii S, Ma LD, Shay JW: Three separate mitochondrial DNA sequences are contiguous in human genome cDNA. J Mol Biol 1989, 2 I 0(4):703-707.

3. Shay JW, Baba T, Zhan QM, Kamimura N, Cuthbert JA: Hela TG cells have mitochondrial DNA inserted into the c-myc oncogene. Mol Gen Genet 1984, 197(3):453-460.

4. Hadler HI, Devadas K, Mahalingam R: Selected nuclear Line elements with mitochondrial-DNA-like inserts are more plentiful and mobile in tumor than in normal tissye of mouse and rat. J Cell Biochem 1998, 68(1):100-109.

5. Xue W, Chen D, Yang Y, Geng J, Lu Y, Lu X, Wang J: Relationship between mitochondrion DNA(mtDNA)and carcinogenesis of human cervical cell. Chinese Journal of Birth Health and Heredity 2005, I 3( I 2):263-265.

6. Chen D, Zhan H: Study on the D-loop region of mitochondrial DNA mutation in cervical carcinomas. In J Cancer Res Clin Oncol Springer-Verlag; 2008.

7. Yide $\mathrm{H}$, Guisheng $\mathrm{Q}$, Baoling M: Malignant transformation of morse embryonic fibroblast induced by mitochondrial DNA fragments. Chinese Journal of Pathology 2000, 29(I):39-42.

8. Xianlong L, Dianchun F, Xiaodong Z: Relationship between integration of $m t D N A$ fragments in the nuclei of gastric mucosal cells and Helicobacterpyiori infection. Acta Academiae Medicinae Militaris Tertiae 200I, 23(9): 1043-1046.

9. Shay JW, Werbin $\mathrm{H}$ : New evidence for the insertion of mitochondrial DNA into human genome: significance for cancer and ageing. Mutation Research 1992, 275(3-6):227-235.

10. Ngan HY: Proto-oncogenes and p53 protein expression in normal cervical stratified squamous epithelium and cervical intra - epithelial neoplasia. Eur J Cancer 1999, 35( I0): I 546- 1550.

II. Aoyama C, Peters J, Senadheera S, Liu P, Shimada H: Links Uterine cervical dysplasia and cancer: identification of c-myc status by quantitative polymerase chain reaction. Diagn Mol Pathol 1998, 7(6):324-330.

12. Zullos A, Sieu LC, Slightom JL: Mitochondrial D-LOOP sequence are integrated in the rat muclear genome. J Mol Biol I991, $22|(4):| 223-|23|$.
Publish with Biomed Central and every scientist can read your work free of charge

"BioMed Central will be the most significant development for disseminating the results of biomedical research in our lifetime. "

Sir Paul Nurse, Cancer Research UK

Your research papers will be:

- available free of charge to the entire biomedical community

- peer reviewed and published immediately upon acceptance

- cited in PubMed and archived on PubMed Central

- yours - you keep the copyright

Submit your manuscript here:

http://www.biomedcentral.com/info/publishing_adv.asp
BioMedcentral 